\title{
Screen-Printed Carbon Electrode Modified with Poly-L-histidine Applied to Gold(III) Determination
}

\author{
Márcio F. Bergamini, Daniela P. Santos and Maria Valnice B. Zanoni* \\ Instituto de Química, Universidade Estadual Paulista, CP 355, 14801-970 Araraquara-SP, Brazil
}

\begin{abstract}
O presente trabalho reporta o desenvolvimento de um novo método voltamétrico para análise de íons ouro(III) usando eletrodo de carbono impresso modificado com poli-L-histidina. O procedimento é baseado no acúmulo do complexo $\left[\mathrm{AuCl}_{4}\right]^{-}$, na superfície do eletrodo sob potencial de circuito aberto e tempo de acúmulo controlado. Parâmetros que influenciam na resposta, tais como: preparação do filme, $\mathrm{pH}$, potencial de acúmulo e tempo de acúmulo, foram otimizados e curvas analíticas para os íons ouro foram construídas usando voltametria de varredura linear (LSV), pulso diferencial (DPV), e onda quadrada (SWV). Limites de detecção de $6,0 \times 10^{-6} \mathrm{~mol} \mathrm{~L}^{-1}$, $1,7 \times 10^{-6} \mathrm{~mol} \mathrm{~L}^{-1} \mathrm{e} 4,0 \times 10^{-6} \mathrm{~mol} \mathrm{~L}^{-1}$ foram obtidos para LSV, DPV e SWV, respectivamente. O método foi aplicado para a determinação de íons ouro em amostras de urina humana.
\end{abstract}

A sensitive voltammetric method for trace measurements of gold(III) ions using a screen-printed carbon electrode modified with poly-L-histidine is described. The new procedure is based on the accumulation of the tetrachloroaurates complex at the electrode surface under an open circuit potential condition, followed by a cathodic stripping scan of potential. Parameters such as film preparation, $\mathrm{pH}$, accumulation potential and deposition time have been optimized to obtain the best voltammetric response. Using optimal experimental conditions, analytical curves for gold ions were obtained using a linear sweep (LSV), differential pulse (DPV), and square wave voltammetry (SWV). Limits of detection of $6.0 \times 10^{-6} \mathrm{~mol} \mathrm{~L}^{-1}, 1.7 \times 10^{-6} \mathrm{~mol} \mathrm{~L}^{-1}$ and $4.0 \times 10^{-6} \mathrm{~mol} \mathrm{~L}^{-1}$ were estimated for the LSV, DPV and SWV, respectively. The method was successfully applied to the determination of gold ions in human urine samples.

Keywords: screen-printed electrode, poly-L-histidine, gold ions, stripping voltammetry

\section{Introduction}

Voltammetric stripping methods involving preconcentration steps are generally very sensitive when used for metal-ion determination. The combination of chemically modified electrodes with stripping methods can offer an excellent alternative for electrochemical analysis of metals at trace levels, ${ }^{1}$ increasing not only the sensitivity but also selectivity of the analysis. A common approach to increasing selectivity is to attach host molecules, which selectively interact with specific guest molecules. The properties of polyaminoacids as host molecules for metal ions have been widely explored. ${ }^{2-5}$ Despite poly-L-lysine having received particular attention as a simple, efficient and rapid supporting material for several applications, polyaminoacids such as poly-L-histidine ( $\mathrm{PH})$ have also

*e-mail: boldrinv@iq.unesp.br been described in literature to catalyze the reduction/ oxidation of some biological compounds. ${ }^{6-10}$

Poli-L-histidine (Figure 1) is a synthetic poliaminoacid with an imidazole group $\left(\mathrm{pK}_{\mathrm{a}}=6.0\right)^{11}$ that can be strongly adsorbed onto the surface of silver metal by covalent bonding and it can be employed to facilitate both the<smiles>CNC(Cc1cnc[nH]1)C(C)C</smiles>

Figure 1. Molecular structure of poly-L-histidine. 
reduction and oxidation of myoglobin and cytochrome ${ }^{6}$ and also used to catalyze the reduction ${ }^{7}$ of $\mathrm{NAD}^{+}$.

Recently, Bergamini et al. ${ }^{8}$ have shown that a chemically modified electrode with poly-L-histidine can be used for chromium (VI) determination in wastewater. Optimum adherence and stability of the poly-L-histidine film (PHfilm) was obtained by direct addition of $1 \% \mathrm{PH}$ solution $(\mathrm{m} / \mathrm{v})$ onto the electrode surface, followed by heating to $80{ }^{\circ} \mathrm{C}$ for $5 \mathrm{~min}$. The $\mathrm{PH}$-film is able to pre-concentrate chromium species at the modified electrode surface, offering a detection limit of around $0.046 \mu \mathrm{mol} \mathrm{L} \mathrm{L}^{-1}$. The coating of glassy carbon and platinum electrodes by $\mathrm{PH}-$ film can also be obtained using electrochemical oxidation of the aminoacid. ${ }^{9}$ The poly-L-histidine-modified electrode has effective catalytic activity on the electrooxidation of ascorbic acid, permitting its determination at low levels of ascorbic acid in the presence of dopamine. Films formed using a poly-L-histidine-copper complex can also be obtained on a polyacrylamide gel and used as an alternative biocatalyst for the L-ascorbate sensor. ${ }^{10}$

Gold drugs have proven effectiveness in treating rheumatoid and psoriatic arthritis and bronchial asthma. ${ }^{12-13}$ Although the bioinorganic chemistry of gold has been well defined, its mechanism of action is poorly understood. For effective evaluation of treatment with gold and the detoxification of gold, analytical methods for the quantitative indication of gold levels in the blood, urine and other biological fluids is necessary; but the available methods are very limited in their ability to estimate gold(III) in biological fluids. Because the levels of gold in the body fluids of patients receiving treatments are usually $<5 \mu \mathrm{g} \mathrm{mL} \mathrm{m}^{-1}$, analytical methods for determinations of total gold and of intact drugs and their metabolites have required detectors which are sensitive to very low concentrations of gold.

Literature $^{14-19}$ has shown that both gold(III) and gold(I) can be determined by electrochemical analysis, in general using chemically modified electrodes under stripping analysis conditions. The main problem with electrochemical stripping analysis of gold(III) is finding a working electrode onto which gold can be deposited for subsequent stripping. In order to improve the efficiency of gold deposition onto a carbon electrode, co-deposition with other metals and activation of the electrode with small amounts of gold have been reported. ${ }^{15,16}$ Bond et al. ${ }^{17}$ have studied the electrochemistry of gold in dilute aqua regia at $\mathrm{Pt}, \mathrm{Rh}, \mathrm{Ir}$ and $\mathrm{Au}$ and $\mathrm{C}$ microdisk electrodes. The best results were obtained with a $50 \mathrm{~mm}$ diameter Pt disk, which offered a detection limit of $4.4 \times 10^{-7} \mathrm{~mol} \mathrm{~L}^{-1}$ (140 s deposition) by anodic stripping voltammetry. Turyan and Madler ${ }^{18}$ proposed a pretreated glassy carbon electrode (GCE) modified with an azacrown ether; which is $8,9,17,18$-dibenzo-1,7-dioxa-10,13,16- triazacyclooctadecane (DDTC), for gold(III) determinations. A detection limit of $4.2 \times 10^{-9} \mathrm{~mol} \mathrm{~L}^{-1}$ was obtained under anodic stripping voltammetry conditions. The method was applied to gold determination in geological samples. Lack et $a l .{ }^{19}$ have proposed a method for gold determination using adsorptive cathodic stripping voltammetry based on the adsorption of yeast mannan, a polysaccharide which consists of chains of mannose units on a glassy carbon electrode. After optimizing the experimental conditions, a limit of detection of $6.0 \times 10^{-8} \mathrm{~mol} \mathrm{~L}^{-1}$ and a serious interference with copper were related. The determination of gold ions on carbon paste electrodes modified with humic acid preparation ${ }^{20}$ and with clay mineral montmorillonite ${ }^{21}$ was also related. These methods accumulated gold in the form of tetrachloroaurates, which is a stable chloro-gold(III) complex in aqueous solution.

Screen-printing techniques for the fabrication of electrodes have facilitated the obtaining of versatile devices. $^{22-25}$ The advantages of this kind of electrode system are its modest cost, potential portability, simplicity of operation, reliability, and their instrumental arrangement. ${ }^{26-29}$ In addition, the rough surface of screen-printed carbon electrodes (SPCEs) has shown itself to be an excellent approach to pre-concentrate substrate on the electrode surface providing more sensitive methods using labconstructed handheld instruments.

In the present study, we report the construction and evaluation of a screen-printed carbon electrode chemically modified with poly-L-histidine film using different procedures of films preparation. Further, screen-printed electrodes modified with poly-L-histidine were applied to the determination of gold(III) based on the preconcentration of the metal on the PH-film electrode surface, with the aim of developing a simple and sensitive method for gold(III) determination in human urine.

\section{Experimental}

\section{Apparatus}

Voltammetric measurements were carried out using a $\mu$ AUTOLAB Type III (EcoChimie) connected to a microcomputer controlled by GPES 4.9 software for data acquisition and experimental control. The measurements were performed in a conventional electrochemical cell of $10.0 \mathrm{~mL}$, where the screen-printed carbon electrode (SPCE) was coupled. The design of the screen-printed carbon electrode (Oxley Developments UK) used in all electrochemical experiments is shown in Figure 2. The electrode is based on an alumina ceramic base (S) $45 \mathrm{~mm}$ long, $10 \mathrm{~mm}$ wide and $0.8 \mathrm{~mm}$ of thick, where working $(\mathrm{W})$, 


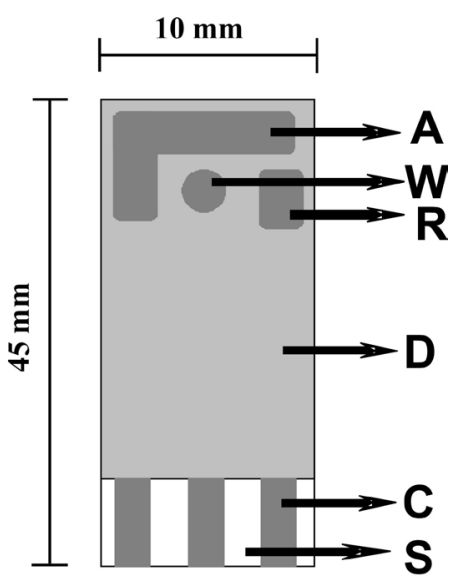

Figure 2. Screen-printed carbon electrode used in the voltammetric measurements. Ceramic substrate (S), dielectric protection layer (D), electric contact (C), working (W), reference (R) and auxiliary (A) electrodes.

reference (R) and auxiliary (A) electrodes are exposed on the ceramic surface. All the electrodes are made of carbon conducting ink. An electrical contact area is placed at the end, which is connected with the active part of each electrode via internally conducting carbon parts (C), covered by a protective dielectric layer. The sensor was connected via a cable to the potentiostat and used without any pretreatment.

\section{Screen-printed modified electrode preparation}

The screen-printed carbon electrode modified with poly-L-histidine $(\mathrm{PH})$ was prepared using three different procedures.

\section{Procedure 1 (SPCE/PH)}

An aliquot of $10.0 \mu \mathrm{L}$ of a PH solution $(1 \%, \mathrm{~m} / \mathrm{v})$ was placed on the screen-printed carbon electrode surface and then submitted to heating for $5 \mathrm{~min}$ at $80^{\circ} \mathrm{C}$. In agreement with poli-L-lisine films, ${ }^{30,31}$ a transformation of the PH structural conformation is expected, improving its adherence to the electrode surface.

\section{Procedure 2 (SPCE/Glu-PH)}

The $\mathrm{PH}$ and glutaraldehyde were prepared using a mixture of PH $(1 \%, \mathrm{~m} / \mathrm{v})$ and glutaraldehyde $(0.05 \%, \mathrm{~m} / \mathrm{v})$ solutions. ${ }^{32} 1.0 \mu \mathrm{L}$ samples of glutaraldehyde solution were placed onto the screen-printed electrode surface where $9.0 \mu \mathrm{L}$ of PH solution was added subsequently. After mixing, the electrode was placed in a drying oven at $80^{\circ} \mathrm{C}$ for $5 \mathrm{~min}$.

\section{Procedure 3 (SPCE/EPH)}

The screen-printed carbon electrode was placed in a $0.1 \mathrm{~mol} \mathrm{~L}^{-1}$ phosphate buffer solution ( $\mathrm{pH} 9.0$ ) containing
$0.02 \mathrm{~mol} \mathrm{~L}^{-1} \mathrm{~L}$-histidine (monomer), which was previously deaerated with nitrogen for 10 minutes. The electrode was submitted to six potential cycles between -0.8 to $+2.0 \mathrm{~V}$ (vs. $\mathrm{Ag} / \mathrm{AgCl}$ ) at a scan rate of $100 \mathrm{mV} \mathrm{s}^{-1}$, adopting methodology previously described in literature. ${ }^{9}$

Sample preparation and analysis of gold ions in human urine

A human urine sample $(10.0 \mathrm{~mL})$ was spiked with a gold standard solution in order to reach a final concentration of $1.0 \times 10^{-4} \mathrm{~mol} \mathrm{~L}^{-1}$ of gold (III). The urine sample $(10.0 \mathrm{~mL})$ was then acidified with $1.0 \mathrm{~mL}$ of hydrochloric acid and the solution was heated for $20 \mathrm{~min}$ at $80^{\circ} \mathrm{C}$ to hydrolyze any proteins that may have been present in the sample. ${ }^{33}$ The solution yielded was diluted with $0.1 \mathrm{~mol} \mathrm{~L}^{-1} \mathrm{KCl}$ (pH 1.0) solution at a ratio $200 \mu \mathrm{L}$ to a $10.0 \mathrm{~mL}$ final volume. The gold-ion content in these samples was determined using the standard addition method of gold(III) stock solution in four successive additions in order to obtain a final added gold ion concentration of 0.5, 1.0, 2.0 and $4.0 \mu \mathrm{mol} \mathrm{L}{ }^{-1}$, respectively.

\section{Results and Discussion}

\section{Voltammetric behavior}

Figures $3 \mathrm{~A}$ and $3 \mathrm{~B}$ present, respectively, cyclic voltammograms obtained for the reduction of $1.0 \times$ $10^{-5} \mathrm{~mol} \mathrm{~L}^{-1}$ gold(III) ions in (A) $0.10 \mathrm{~mol} \mathrm{~L}^{-1} \mathrm{KNO}_{3}$ (pH 1.0) and (B) $0.10 \mathrm{~mol} \mathrm{~L}^{-1} \mathrm{KCl}(\mathrm{pH} \mathrm{1.0)}$ ), after $60 \mathrm{~s}$ of pre-accumulation at open circuit potential on the unmodified screen-printed carbon electrode (curve a) and on the modified screen-printed carbon electrodes (curve b). Films of poly-L-histidine (SPCE/PH) were obtained by the direct addition of poli-L-histidine solutions onto the electrode surface. On the unmodified electrode, the voltammograms exhibited a well-defined reduction peak at around $+0.44 \mathrm{~V}$ (vs. $\mathrm{Ag} / \mathrm{AgCl}$ ) in $\mathrm{KCl}$ medium and $+0.55 \mathrm{~V}$ (vs. $\mathrm{Ag} / \mathrm{AgCl})$ in the $\mathrm{KNO}_{3}$ medium. This peak current can be attributed to the reduction of gold(III) species to $\operatorname{gold}(\mathrm{I}) .^{17,19,33}$ The response on the screen-printed carbon electrode coated with poly-L-histidine (SPCE/PH) film is essentially the same. However, there is an increase in the peak intensity for both experiments (curve b), while a bigger increase is observed in the chloride medium. This result indicates that the poli-L-histidine film can pre-concentrate gold(III) due to electrostatic interaction or as a complexing agent.

The formation of gold(III) complex with histidine aminoacid is well known in literature. ${ }^{34}$ But as shown 

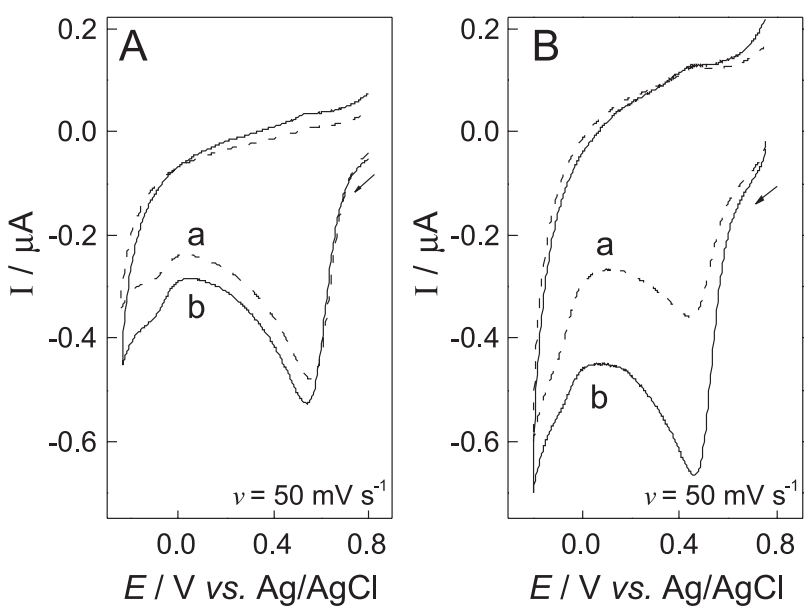

Figure 3. Cyclic voltammograms obtained for the reduction of a solution of $1.0 \times 10^{-5} \mathrm{~mol} \mathrm{~L}^{-1}$ gold(III) in $\mathrm{KNO}_{3} 0.1 \mathrm{~mol} \mathrm{~L}^{-1}$ at $\mathrm{pH} 1.0$ (A) and $0.1 \mathrm{~mol} \mathrm{~L}^{-1} \mathrm{KCl}$ at $\mathrm{pH} 1.0$ (B) on a screen-printed carbon electrode without modification (curve a) and modified with poly-L-histidine SPCE/PH (curve b). Reference electrode: $\mathrm{Ag} / \mathrm{AgCl}$.

in Figure 4, the equilibrium between species of tetrachloroaurate(III) complex formed in $0.1 \mathrm{~mol} \mathrm{~L}^{-1}$ of chloride ions should be also considered $\left(\log \mathrm{K}_{1}=9.26\right.$, $\log \mathrm{K}_{2}=8.31, \log \mathrm{K}_{3}=7.31$ and $\left.\log \mathrm{K}_{4}=6.16\right)$. The influence of chloride medium on the intensity peak obtained for gold(III) on the modified electrode in comparison with the poor increment observed for nitrate medium, indicates that probably the mechanism for the pre concentration of gold(III) is preponderantly due to the formation of an ion pair between the negatively-charged tetrachloroaurate(III), $\left[\mathrm{AuCl}_{4}\right]^{-}$, and the positively-charged imidazole group present in the polyaminoacid. Thus, we suggest that the mechanism for the increasing the reduction wave in a solution containing

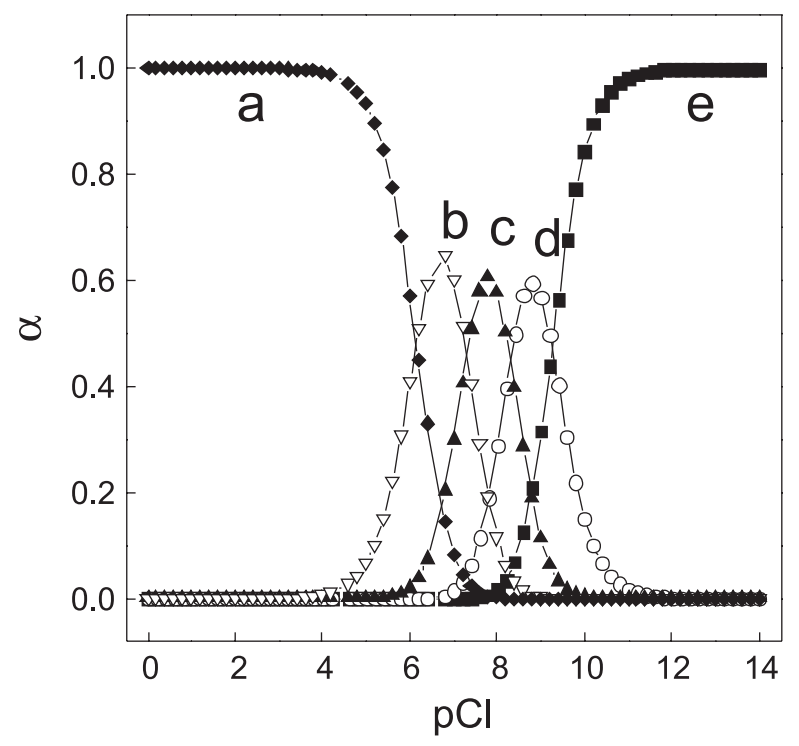

Figure 4. Diagram of the distribution of gold(III) chloride complex species as a function of $\mathrm{pCl}$. The $\left[\mathrm{AuCl}_{4}\right]^{-},\left[\mathrm{AuCl}_{3}\right],\left[\mathrm{AuCl}_{2}\right]^{+}[\mathrm{AuCl}]^{2+}$ and $\left[\mathrm{Au}^{3+}\right]$ species were represented by $\mathrm{a}, \mathrm{b}, \mathrm{c}, \mathrm{d}$ and e, respectively. chloride ions can be attributed to the chemical equilibrium involving gold(III) ions and its mutual transformation to tetrachloroaurates $\left(\mathrm{Au}^{3+}+4 \mathrm{Cl}^{-} \rightleftharpoons\left[\mathrm{AuCl}_{4}\right]^{-}\right)$. This anionic specie can be accumulated onto poly-L-histidine films by electrostatic interaction with the protonated imidazole group ( $\mathrm{pK}_{\mathrm{a}}$ 6.0). Initial studies were carried out disregarding the carbon ink as a pseudo reference, which was changed to a conventional $\mathrm{Ag} / \mathrm{AgCl}$ reference used with the screenprinted carbon electrode as the working electrode. In order to use the carbon ink electrode without an external reference electrode, cyclic voltammograms obtained for $2.0 \times 10^{-5} \mathrm{~mol} \mathrm{~L}^{-1} \operatorname{gold}(\mathrm{III})$ in $0.10 \mathrm{~mol} \mathrm{~L}^{-1} \mathrm{KCl}(\mathrm{pH} 1.0)$ on the screen-printed carbon electrode was compared to that using a conventional reference of $\mathrm{Ag} / \mathrm{AgCl}$, where the potential is measured against a pseudo reference electrode. Despite a shifting of around $400 \mathrm{mV}$ to a less positive potential on the screen-printed electrode, which was constant in all the voltammograms recorded, there were no other modifications.

The influence of film preparation on the voltammetric response of a screen-printed carbon electrode coated with a poly-L-histidine film was compared testing the following procedures (i) (SPCE/EPH) electropolymerization of histidine solution in phosphate buffer $\mathrm{pH} 9.0$ as described in literature ${ }^{9}$ (ii) (SPCE/ PH) by direct addition of poly-Lhistidine solution $(1 \%, \mathrm{~m} / \mathrm{v})^{30,31}$ and (iii) (SPCE/Glu-PH) by mixture of poly-L-histidine/glutaraldehyde solution $(1: 0.05 \%, \mathrm{~m} / \mathrm{v}){ }^{32}$ The modified electrodes were transferred to a voltammetric cell containing $1.0 \times 10^{-5} \mathrm{~mol} \mathrm{~L}^{-1}$ of gold(III) in $\mathrm{KCl}$ ( $\mathrm{pH} 1.0$ ). The corresponding cyclic voltammograms were obtained at $50 \mathrm{mV} \mathrm{s}^{-1}$. The reduction of gold(III) at all the modified PH-film electrodes takes place at a slightly more positive potential than at a bare electrode and promotes an increase in the peak current, whose intensity is according to the following sequence: SPCE/PH < SPCE/Glu-PH < SPCE/EPH, respectively.

In order to test the adherence of the film formed, the electrodes prepared using the different procedures was loaded with the analyte by immersing it in $1.0 \times 10^{-5} \mathrm{~mol} \mathrm{~L}^{-1}$ gold(III) in $\mathrm{KCl}$ solution ( $\mathrm{pH} 1.0)$ for $60 \mathrm{~s}$. The results indicate that films formed by direct evaporation of poly-L-histidine solution on the electrode surface present higher adherence on the screen printed carbon electrode and higher peak current, probably because this electrode presents more available sites on the electrode surface to pre-concentrate the gold(III) complex. Therefore, this experimental condition was adopted as the best way to prepare $\mathrm{PH}$-films on the screen-printed carbon electrode surface with the aim of determining gold(III).

The effect of $\mathrm{pH}$ on the voltammetric response of the screen-printed carbon electrode was studied over a $\mathrm{pH}$ range between 1.0 and 4.0 in a $0.1 \mathrm{~mol} \mathrm{~L}^{-1} \mathrm{KCl}$ solution containing 
$3.0 \times 10^{-5} \mathrm{~mol} \mathrm{~L}^{-1}$ gold ions, submitting it to $60 \mathrm{~s}$ at open circuit potential. Above $\mathrm{pH} 4.0$, there was no voltammetric signal probably due a hydrolysis reaction involving gold ions. ${ }^{21}$ Nevertheless, in the interval $1.0 \leq \mathrm{pH} \leq 3.0$ the peak current increases markedly up to $\mathrm{pH} 1.0$, where maximum peak current is obtained. Studies at lower $\mathrm{pH}$ values were not conducted because of potential deletion effects on the material used to construct the screen-printed electrode. Thus a $\mathrm{pH}$ of 1.0 was chosen for further studies.

Voltammograms obtained for $4.0 \times 10^{-5} \mathrm{~mol} \mathrm{~L}^{-1}$ gold(III) in $\mathrm{KCl}(\mathrm{pH} 1.0)$ for $60 \mathrm{~s}$ of pre-accumulation at varied potentials from 0.4 to $1.0 \mathrm{~V}$ and at open circuit potential do not show any significant variation. The voltammetric responses obtained were practically independent of the potential applied, confirming that gold(III) ions are being electrostatically accumulated. Thus, an open circuit potential was selected for the accumulation step in the subsequent studies.

The influence of the accumulation time on the peak current was studied using concentration levels of $8.0 \times 10^{-6} \mathrm{~mol} \mathrm{~L}^{-1}$ of gold(III) in $0.1 \mathrm{~mol} \mathrm{~L}^{-1} \mathrm{KCl}(\mathrm{pH} 1.0)$ solution, submitted to previous accumulation from 0 to $90 \mathrm{~s}$. The peak current increases linearly with accumulation time until reaching constant values for longer accumulation times, indicating saturation of the electrode surface. Therefore, a step having a pre-concentration time of $60 \mathrm{~s}$ was chosen to further studies.

In order to optimize an electroanalytical method with good sensitivity, the response for gold(III) on a screenprinted electrode coated with poly-L-histidine film was compared by using linear sweep, differential pulse and square wave voltammetry.

\section{Analytical curves}

The effect of scan rate on the voltammetric response was evaluated using SPCE/PH electrodes in $5.0 \times 10^{-5} \mathrm{~mol} \mathrm{~L}^{-1}$ gold(III) in $\mathrm{KCl}$ (pH 1.0). The cathodic peak current varied linearly with the square root of the scan rate for scan rates from 5 to $100 \mathrm{mV} \mathrm{s}^{-1}$, following the equation: $\mathrm{I}_{\mathrm{pc}}(\mu \mathrm{A})=$ $-4.55 \times 10^{-2}+2.32 \times 10^{-2} v^{1 / 2}$. These results suggest that the gold ions reduction is controlled by diffusion thorough the modified electrode. Further experiments were carried out at a scan rate of $50 \mathrm{mV} \mathrm{s}^{-1}$, where the best voltammetric signal was obtained. Under optimized conditions, an analytical curve was obtained for LSV. A linear relationship between peak current and the gold(III) concentration in the range $1.2 \times 10^{-5}$ from $1.1 \times 10^{-4} \mathrm{~mol} \mathrm{~L}^{-1}$ was observed, following the equation: $-\mathrm{I}_{\mathrm{pc}}(\mu \mathrm{A})=0.38+36.2 \mathrm{C}_{\mathrm{Au}}{ }^{3+}\left(\mathrm{mmol} \mathrm{L}^{-1}\right)$. The detection limit, based on three times the standard deviation of the intercept/slope, ${ }^{34}$ was $6.0 \times 10^{-6} \mathrm{~mol} \mathrm{~L}^{-1}$.
The influence of voltammetric parameters of the SPCE/PH electrode for gold(III) was investigated using differential pulse voltammetry testing, scan rate $\left(2-10 \mathrm{mV} \mathrm{s}^{-1}\right)$, pulse amplitude $(20-100 \mathrm{mV})$ and pulse duration (2-15 ms). At the proposed electrode, the reduction peak at $+0.44 \mathrm{~V}(v s . \mathrm{Ag} / \mathrm{AgCl})$ presented higher peak currents and a better voltammetric profile at a scan rate of $10 \mathrm{mV} \mathrm{s}^{-1}$, pulse amplitude of $50 \mathrm{mV}$ and a pulse duration of $10 \mathrm{~ms}$. Under such conditions, an analytical curve (Figure 5) was obtained presenting a linear relationship from $4.9 \times 10^{-6}$ to $8.7 \times 10^{-5} \mathrm{~mol} \mathrm{~L}^{-1}$, following the equation: $-\mathrm{I}_{\mathrm{pc}}(\mu \mathrm{A})=0.30+65.2 \times 10^{-2} \mathrm{C}_{\mathrm{Au}}{ }^{3+}\left(\mathrm{mmol} \mathrm{L}^{-1}\right)$. A detection limit of $1.7 \times 10^{-6} \mathrm{~mol} \mathrm{~L}^{-1}$ was estimated.

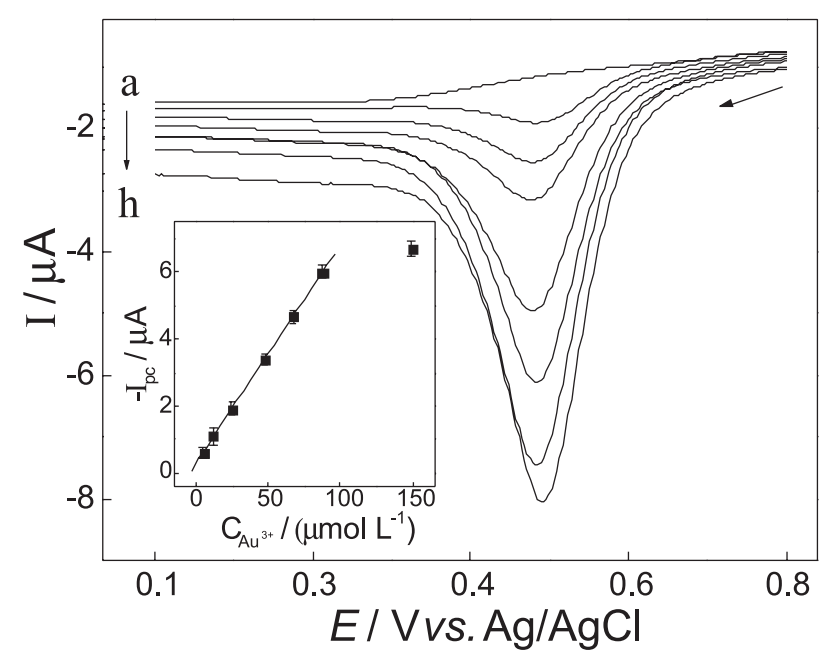

Figure 5. Differential pulse cathodic voltammograms obtained under optimized conditions in $0.1 \mathrm{~mol} \mathrm{~L}^{-1} \mathrm{KCl}$ ( $\mathrm{pH} 1.0$ ) solution containing (a) 0.0 ; (b) $4.8 \times 10^{-6}$, (c) $1.2 \times 10^{-5}$, (d) $2.5 \times 10^{-5}$, (e) $4.8 \times 10^{-5}$, (f) $6.7 \times$ $10^{-5}$, (g) $8.7 \times 10^{-5}$, (h) $1.5 \times 10^{-4} \mathrm{~mol} \mathrm{~L}^{-1}$ of gold(III) ions. The analytical curve is shown in the inset.

The peak current obtained for SWV is dependent on various instrumental parameters and this method was investigated for gold(III) on a SPCE/PH electrode changing the pulse amplitude (10-100 mV), square wave frequency $(10-150 \mathrm{~Hz})$, and step height $(1-25 \mathrm{mV})$. The optimum conditions for the analysis of gold(III) using square wave voltammetry were: amplitude of $50 \mathrm{mV}$, since it presented a well-defined voltammetric profile in all cases, frequency of $10 \mathrm{~Hz}$ and a step of $5 \mathrm{mV}$. Under these conditions, a linear dynamic range was observed for gold(III) from $8.9 \times 10^{-6}$ to $6.0 \times 10^{-5} \mathrm{~mol} \mathrm{~L}^{-1}$ according to the equation: $-\mathrm{I}_{\mathrm{pc}}(\mu \mathrm{A})=0.8+96.2 \mathrm{C}_{\mathrm{Au}(\mathrm{III})}\left(\mathrm{mmol} \mathrm{L}^{-1}\right)$. A detection limit of $4.0 \times 10^{-6} \mathrm{~mol} \mathrm{~L}^{-1}$ was obtained.

Table 1 compiles the best performances obtained for all the techniques employed (LSV, DPV and SWV) for the determination of gold(III) at the SPCE/PH in $\mathrm{KCl}$ at $\mathrm{pH}$ 1.0. The methods offer a linear dynamic range (LDR) from 
$4.9 \times 10^{-6}$ to $1.1 \times 10^{-4} \mathrm{~mol} \mathrm{~L}^{-1}$. Despite the SWV showing highest sensitivity, the best detection limit and the best waves are reached using DPV. So, the DPV technique was chosen for analytical application.

Table 1. Results obtained for gold(III) ion determination using the proposed electrode and different voltammetric techniques

\begin{tabular}{lccc}
\hline Technique & $\begin{array}{c}\text { LDR / } \\
\left(\mathrm{mol} \mathrm{L}^{-1}\right)\end{array}$ & $\begin{array}{c}\text { Sensitivity / } \\
(\mu \mathrm{A} \mathrm{mmol} \mathrm{L})^{-1}\end{array}$ & $\begin{array}{c}\text { LOD / } \\
\left(\mathrm{mol} \mathrm{L}^{-1}\right)\end{array}$ \\
\hline LSV & $1.2 \times 10^{-5}-1.1 \times 10^{-4}$ & 36.2 & $6.0 \times 10^{-6}$ \\
DPV & $4.9 \times 10^{-6}-8.7 \times 10^{-5}$ & 65.2 & $1.7 \times 10^{-6}$ \\
SWV & $8.9 \times 10^{-6}-6.0 \times 10^{-5}$ & 96.2 & $4.0 \times 10^{-6}$ \\
\hline
\end{tabular}

In order to investigate the possibility of applying the proposed method to the determination of gold ions in urine samples, a study was carried out to determine the matrix effect on the reduction peak current.

The interference in the resulting peak obtained for samples of $\mathrm{KCl}$ at $\mathrm{pH} 1.0$ containing different volumes of urine samples without pretreatment spiked to $1.0 \times$ $10^{-5} \mathrm{~mol} \mathrm{~L}^{-1}$ of gold(III) is shown in Figure 6 (curve B), whose values are expressed as recovery data. The recovery is more than $90 \%$ only for samples involving a maximum of $30 \mu \mathrm{L}$ of urine. The results suggest that the method should be practiced only for analysis where small quantities of urine sample are transferred. According to literature, ${ }^{36}$ sulfur compounds such as human serum albumin can complex gold more preferentially than the polyaminoacids in a urine sample without pretreatment. Thus, this effect could be responsible for the strong interference observed in Figure 6 (curve B). From the results given above, it is apparent that the direct determination of the drug in urine by cathodic stripping voltammetry is not possible.

For this reason, a pretreatment of the urine sample was tested before voltammetric analysis. A urine sample spiked to $1.0 \times 10^{-5} \mathrm{~mol} \mathrm{~L}^{-1}$ of gold(III) was submitted to cleanup as described in the experimental section and different aliquots were transferred to $10.0 \mathrm{~mL}$ of $\mathrm{KCl}$ at $\mathrm{pH} 1.0$. The sample was submitted to the standard addition method and the results obtained are shown in Figure 6 (curve A). Using the urine sample after pretreatment, it was possible to obtain a good recovery for all analyzed samples with the recovery above $95 \%$. Thus, the pretreatment step plays an important role in gold-ion determination in urine samples and it was adopted for this application.

Finally, the proposed method was applied to the differential pulse stripping voltammetric determination of gold ions in a human urine sample coupled with a clean-up step presented in the experimental section. Recoveries of $97 \%$ to $104 \%$ of gold ions were obtained for urine samples $(\mathrm{n}=3)$ spiked to $0.5,1.0,2.0$ and $4.0 \times 10^{-6} \mathrm{~mol} \mathrm{~L}^{-1}$ of gold ions analyzed using

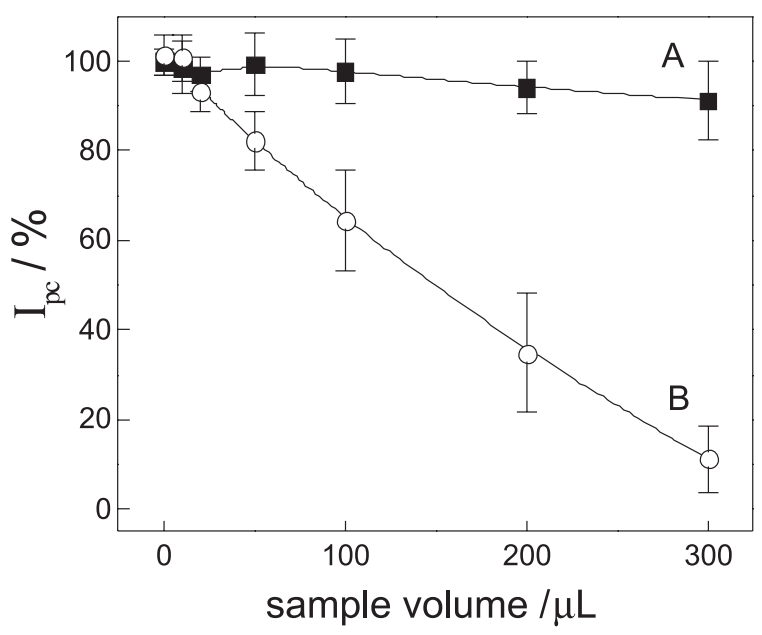

Figure 6. Matrix effect on the cathodic current recovery using urine samples (with (A) and without (B) pretreatment) spiked with $1.0 \times 10^{-5} \mathrm{~mol} \mathrm{~L}^{-1}$ of gold(III) ions as a function of sample volume added.

the screen-printed PH-film-modified carbon electrode. This is an evidence of the accuracy of the proposed procedure. The statistical calculations for the results suggest good precision for the voltammetric method. According to the $t$-test, there were no significant differences between the recoveries and added values at the $95 \%$ confidence level ${ }^{35}$ and the results were also within an acceptable range of error, indicating that the screen-printed carbon electrode can be used for voltammetric determinations of gold ions in such samples.

\section{Conclusions}

Our findings indicate that the screen-printed electrode modified with poly-L-histidine can be used for gold(III) determination. Reproducible, accurate and sensitive determination can be obtained using the differential pulse voltammetric procedure. Other advantages of this method are low analysis costs, fast response time and simplicity. The method was successful applied to the determination of gold(III) in human urine samples after a simple cleaning-up of the original sample, offering good recovery and a simple method of analysis.

\section{Acknowledgments}

The authors thank financial support from FAPESP, CAPES and CNPq and the scholarships obtained from FAPESP (process number: 04/00111-8 (MFB) and 03/06598-3 (DPS)).

\section{References}

1. Teixeira, M. F. S.; Bergamini, M. F.; Bocchi, N.; Talanta 2004 , 62,603 . 
2. Fogg, A. G.; Pirzad, R.; Moreira, J. C.; Davies, A. E.; Anal. Proc. 1995, 32, 209.

3. Pereira, F. C.; Fogg, A. G.; Ugo, P.; Bergamo, E. P.; Stradiotto, N. R.; Zanoni, M. V. B.; Electroanalysis 2005, 17, 1309.

4. Pereira, F. C.; Fogg, A. G.; Zanoni, M. V. B.; Talanta 2003, 60, 1023.

5. Viana, E. R. C.; Pereira, F. C.; Zanoni, M. V. B.; Dyes Pigm. 2006, 71, 148.

6. Li, G.; Chen, L.; Zhu, J.; Zhu, D.; Untereker, D. F.; Electroanalysis 1999, 11, 139.

7. Long, Y. T.; Chen, H. Y.; J. Electroanal. Chem. 1997, 440, 239.

8. Bergamini, M. F.; Santos, D. P.; Zanoni, M. V. B.; Sens. Actuators, B 2007, 123, 902.

9. Yu, A. M.; Sun, D. M.; Gu, H. Y.; Chen, H. Y.; Anal. Lett. 1996, 29, 2633.

10. Hasebe, Y.; Akiyama, Y.; Yagisawa, T.; Uchiyama, S.; Talanta 1998, 47, 1139.

11. Harris, D. C.; Análise Química Quantitativa, $6^{\text {th }}$ ed., LTC: Rio de Janeiro, 2001.

12. Shaw, C. F.; Chem. Rev. 1999, 99, 2589.

13. Natelson, S.; Zuckerman, J. L.; Anal. Chem. 1951, 23, 653.

14. Barefoot, R. R.; Van Loon, J. C.; Anal. Chim. Acta 1996, 334, 5.

15. Huiliang, H.; Jagner, D.; Renman, L.; Anal. Chim. Acta 1988, 208, 301.

16. Korolczuk, M.; Fresenius J. Anal. Chem. 1996, 356, 480.

17. Bond, A. M.; Kratsis, S.; Mitchell, S.; Macak, J.; Analyst 1997, 122, 1147.

18. Turyan, I.; Mandler, D.; Anal. Chem. 1993, 65, 2089.

19. Lack, B.; Duncan, J.; Nyokong, T.; Anal. Chim. Acta 1999, 385, 393.

20. Wang, C.; Zhang, H.; Sun, Y.; Hulin, L.; Anal. Chim. Acta 1998, $361,133$.
21. Kula, P.; Navratilova, Z.; Electroanalysis 2001, 13, 795.

22. Hart, J. P.; Wring, S. A.; Trends Anal. Chem. 1997, 16, 89.

23. Ashley, K.; J. Hazard. Mater. 2003, 102, 1.

24. Honeychurch, K. C.; Hart, J. P.; Trends Anal. Chem. 2003, 22 , 456.

25. Hart, J. P.; Wring, S. A.; Electroanalysis 1994, 6, 617.

26. Bergamini, M. F.; Santos, A. L.; Stradiotto, N. R.; Zanoni, M. V. B.; J. Pharm. Biomed. Anal. 2005, 39, 54.

27. Bergamini, M. F.; Santos, A. L.; Stradiotto, N. R.; Zanoni, M. V. B.; J. Pharm. Biomed. Anal. 2007, 43, 315.

28. Tsai, D.; Kumar, A. S.; Zen, J.; Anal. Chim. Acta 2006, 556, 145.

29. Laschi, S.; Palchetti, I.; Mascini, M.; Sens. Actuators, B 2006, 114,460

30. Anson, F. C.; Saveant, J. M.; Shigehara, K.; J. Am. Chem. Soc. 1983, 105, 1096

31. Anson, F. C.; Ohsaka, T.; Saveant, J. M.; J. Am. Chem. Soc. 1983, 105, 4883.

32. Pereira, F. C.; Bergamo, E. P.; Stradiotto, N. R.; Zanoni, M. V. B.; Fogg, A. G.;. Electroanalysis 2004, 16, 1439.

33. Bergamini, M. F.; Zanoni, M. V. B.; Electroanalysis 2006, 18, 1457.

34. Cuadrado, J. A.; Zhang, W. X.; Hang, W.; Majidi, V.; J. Environ. Monit. 2000, 2, 355.

35. Miller, J. C.; Miller, J. N.; Statistics for Analytical Chemistry, $3^{\text {th }}$ ed., Chickester: Ellis Horwood, 1993.

36. Coffer, M. T.; Shaw III, C. F.; Eidsness, M. K.; Watkins II, J. W.; Elder, R. C.; Inorg. Chem. 1986, 25, 333.

Received: July 12, 2007

Web Release Date: November 18, 2008

FAPESP helped in meeting the publication costs of this article. 